\title{
Risk Factors of Premature Rupture of Membrane
}

\author{
Faktor Risiko Ketuban Pecah Dini
}

\section{Maryuni, Dedeh Kurniasih}

\author{
Midwifery Studies Institute of Health Science Binawan, Jakarta, Indonesia
}

\begin{abstract}
Maternal mortality rate in Indonesia based on 2012 Indonesia Demographic and Health Survey is 359 per 100,000 live births. Causes of the maternal mortality are still dominated by bleeding, pre-eclampsia/eclampsia and infections. One of causes of infections is premature rupture of membrane. Premature rupture of membrane may increase morbidity and mortality among mothers and children. Incidence of premature rupture of membrane amount to $10 \%$ of all childbirths. This study aimed to analyze risk factors of premature rupture of membrane incidence at Mother and Child Hospital of ANNISA Citeureup, Bogor District in 2014. This study was analytical and used a case control design. The samples consisted of 114 mothers who suffered from premature rupture of membrane and control, 228 mothers who did not suffer from premature rupture of membrane. Results of this study showed that risk factors of premature rupture of membrane were age, parity and education. Based on multivariate analysis, education was the most dominant risk factor for premature rupture of membrane incidence.
\end{abstract}

Keywords: Education, pregnancy, premature rupture of membrane

\section{Abstrak}

Angka kematian ibu di Indonesia berdasarkan Survei Demografi dan Kesehatan Indonesia tahun 2012 sebanyak 359 per 100.000 kelahiran hidup. Penyebab kematian ibu tersebut masih didominasi oleh pendarahan, pre-eklampsia/eklampsia, dan infeksi. Salah satu penyebab infeksi adalah ketuban pecah dini. Ketuban pecah dini dapat meningkatkan morbiditas dan mortalitas pada ibu dan anak. Insiden kejadian ketuban pecah dini sekitar 10\% dari seluruh persalinan. Penelitian ini bertujuan untuk mengetahui faktor risiko kejadian ketuban pecah dini di Rumah Sakit lbu dan Anak (RSIA) ANNISA Citeureup, Kabupaten Bogor tahun 2014. Penelitian ini merupakan penelitian analitik dengan rancangan penelitian kasus kontrol. Sampel terdiri dari 114 orang kasus ibu yang mengalami ketuban pecah dini dan kontrol sebanyak 228 ibu bersalin yang tidak mengalami ketuban pecah dini. Hasil penelitian menunjukkan faktor risiko terhadap kejadian ketuban pecah dini yaitu usia, paritas dan pendidikan. Berdasarkan analisis multivariat, didapatkan faktor yang paling dominan berisiko terhadap kejadian ketuban pecah dini yaitu pendidikan.

Kata kunci: Pendidikan, kehamilan, ketuban pecah dini

How to Cite: Maryuni, Kurniasih D. Risk factors of premature rupture of membrane. Kesmas: National Public Health Journal. 2017; 11 (3): 133-137. (doi:10.21109/kesmas. v11i3.1153)
Correspondence: Maryuni, Midwifery Studies Binawan Institute of Health Science, Kalibata Raya street No 25-30, Jakarta, Phone: +6221 8011777, e-mail: maryuni80@gmail.com Received: August $9^{\text {th }} 2016$ Revised: November $11^{\text {th }} 2016$ Accepted: January $16^{\text {rd }} 2017$ 


\section{Introduction}

Every year, around the world, there are approximately 358,000 maternal deaths of which about $99 \%$ occurred in poor countries and about $67 \%$ in developing countries including Indonesia. ${ }^{1}$ Maternal mortality rate (MMR) and infant mortality rate (IMR) are highest in developing countries. Mortality and morbidity among pregnant and birth-giving women are thus significant issues in developing countries. The MMR in Indonesia based on 2012 Indonesia Demography and Health Survey (IDHS) data, was 359 per 100,000 live births, and IMR was 32 per 1,000 live births. ${ }^{2}$

Ministry of Health stated that West Java is one of nine provinces that contributes $70 \%$ of the Indonesian maternal mortality. West Java Province has the highest maternal mortality rate at 321 per 100,000 live births and it decreases to 123.29 per 100,000 live births in 2009. About 809 mothers are died because of bleeding, pre-eclampsia/eclampsia and infections. One of infection causes is premature rupture of membrane. ${ }^{3}$

Premature rupture of membrane is defined as the leak of amniotic membrane before childbirth and less than 37 weeks gestation. Premature rupture of membrane incidence is about $3-10 \%$ of childbirth. Premature rupture of membrane incidence is almost $10 \%$ of all childbirths, $11 \%$ occurred in America and more in developing countries. Premature rupture of membrane is the factor causing premature birth, also the high rate of perinatal pain and death. Moreover, $40 \%-75 \%$ of deaths on neonatal occurred because of premature rupture of membrane. ${ }^{4}$ In China, premature rupture of membrane incidence with the age of pregnancy less than 37 weeks is $2.7 \%$ of $3 \%$ all cases of childbirth with premature rupture of membrane. ${ }^{5}$ Premature rupture of membrane is wifery case that often occurs related to complications, both among mothers and fetus, even though pathogenesis of premature rupture of membrane itself is not yet known. ${ }^{6}$

The quite high perinatal mortality is caused by deaths due to preterm partus, and the increasing incidence of infections because of obstructed labor, prolonged labor and artificial labor often found in premature rupture of membrane case management. ${ }^{7}$ Women with premature rupture of membrane are 50\% more likely to give birth in 24 to 48 hours, $70 \%-90 \%$ to give birth in 7 days. Premature rupture of membrane relates to the increase of perinatal mortality and neonatal pain rate. Complications on perinatal include breathing disorder syndrome, infections, intraventricular bleeding, hypoplasia pulmonary and bone disorders as well as umbilical cord prolapse. ${ }^{8}$

Cause of premature rupture of membrane is not yet known certainly, however, the possible predisposing factor is infection that occurs directly in amniotic membrane or asenderen from vagina or cervix. Moreover, abnormal physiology of amniotic membrane, incompetent cervix, fetal malposition, younger than 20 years and older than 35 years age of women, blood type factor, multi-gravidity/parity factor, smoking, socio-economic condition, antepartum bleeding, abortus records and prior preterm partus, previous premature rupture of membrane records, nutrition deficiency including bronze or ascorbic acid, excessive tension of uterus, narrow hips, mother's fatigue at work, and trauma suffered such as sexual intercourse, internal check up and amniocentesis. ${ }^{9}$

Several risk factors of premature rupture of membrane incidence include intrauterine infection at early pregnancy, the low social status of pregnant women, lack of treatment during pregnancy, the low nutritional status during pregnancy, sexual transmitted infections, bleeding per vaginam, smoking during pregnancy and heavy weight of fetus. ${ }^{4}$ Premature rupture of membrane incidence at Mother and Child Hospital of ANNISA Citeureup, Bogor District in 2012 was 232 cases, 305 cases in 2013 as increased by $30 \%$ and 424 cases in 2014 as increased by $38 \%$. This study aimed to analyze risk factors of premature rupture of membrane incidence at Mother and Child Hospital of ANNISA Citeureup, Bogor District in 2014.

\section{Method}

This study was analytical study using case control design. Population of study consisted of case population (birth-giving mothers suffering from premature rupture of membrane) and control population (birth-giving mothers who did not suffer from premature rupture of membrane) at Mother and Child Hospital of ANNISA Citeureup, Bogor District in a year from January to December 2014. This study aimed to analyze risk factors of premature rupture of membrane incidence at Mother and Child Hospital of ANNISA Citeureup, Bogor District in 2014. Samples consisted of case as many as 114 mothers who suffered from premature rupture of membrane and control as many as 228 mothers who did not suffer. Variables of this study consisted of independent variables, namely age, parity, multiple pregnancy, malposition and education; and the dependent variable was premature rupture of membrane. Data collection in this study used medical records of childbirth, and reports of birth-giving mothers who suffered and did not suffer from premature rupture of membrane. Instrument used was in the form of checklist. Statistical analysis technique used bivariate and multivariate. The $\mathrm{p}$ value of less than 0.05 was taken as significant. Inclusion of criteria were all birth-giving mothers who suffered from premature rupture of membrane at gestational age 37 weeks to 42 weeks and recorded on medical record. Exclusion criteria were birth-giving mothers who suffered from premature rupture of membrane at gestational age less than 28 weeks or more than 42 weeks and not recorded on medical records. 
Table 1. Bivariate and Multivariate Results

\begin{tabular}{|c|c|c|c|c|c|c|c|}
\hline \multirow{2}{*}{ Variable } & \multirow{2}{*}{ Category } & \multicolumn{2}{|c|}{ Case } & \multicolumn{2}{|c|}{ Control } & \multirow{2}{*}{ p Value } & \multirow{2}{*}{ OR $(95 \% \mathrm{CI})$} \\
\hline & & $\mathbf{n}$ & $\%$ & n & $\%$ & & \\
\hline \multirow[t]{2}{*}{ Age } & Risky & 71 & 62.3 & 87 & 38.2 & 0.000 & $2.676(1.683-4.254)$ \\
\hline & Not risky & 43 & 37.7 & 141 & 61.8 & & \\
\hline \multirow{2}{*}{ Parity } & Second child or more & 58 & 50.8 & 78 & 34.2 & 0.003 & $1.992(1.260-3.149)$ \\
\hline & First Child & 56 & 49.2 & 150 & 65.8 & & \\
\hline \multirow[t]{2}{*}{ Multiple disorders } & Yes & 9 & 7.8 & 0 & 0.0 & 0.000 & $2.000(2.707-3.715)$ \\
\hline & No & 105 & 92.2 & 228 & 100 & & \\
\hline \multirow[t]{2}{*}{ Malposition } & Yes & 13 & 11.4 & 0 & $0.0 \%$ & 0.000 & $2.960(2.769-3.832)$ \\
\hline & No & 101 & 88.6 & 228 & 100 & & \\
\hline \multirow[t]{2}{*}{ Education } & Lower than junior high school & 65 & 57.1 & 61 & 26.8 & 0.000 & $3.632(2.264-5.827)$ \\
\hline & Junior high school and higher & 49 & 42.9 & 167 & 73.2 & & \\
\hline
\end{tabular}

Table 2. Analysis Results of Logistic Regression Multivariate Model in Every Variable

\begin{tabular}{lllllll}
\hline \multirow{2}{*}{ Variable } & \multirow{2}{*}{ B } & S.E & Sig & Exp (B) & \multicolumn{2}{c}{$95 \%$ CI } \\
\cline { 5 - 7 } & & & & & Lower & Upper \\
\hline Age & .945 & .250 & .000 & 2.573 & 1.577 & 4.199 \\
Parity & .681 & .251 & .007 & 1.976 & 1.208 & 3.231 \\
Education & 1.283 & .251 & .000 & 3.606 & 2.205 & 5.898 \\
\hline Constant & -3.830 & .689 & .000 & .022 & & \\
\hline
\end{tabular}

\section{Results}

Study results of influence of age to premature rupture of membrane incidence could be presented in Table 1 . Based on Table 1, there was a significant relation between age and premature rupture of membrane incidence ( $\mathrm{p}$ value $=0.000)$ and $\mathrm{OR}=2.676$ which means that mothers aged $<20$ years and $>35$ years were 2.676 times at risk of suffering from premature rupture of membrane. There was a significant relation between parity and premature rupture of membrane incidence ( $\mathrm{p}$ value $=0.003$ ) and $\mathrm{OR}=1.992$ which means that mothers who gave birth 2 or > were 1.992 times at risk of suffering from premature rupture of membrane. This study also showed there was a significant relation between multiple pregnancy and premature rupture of membrane, results of chi square test showed $p=0.000<0.05$. Results of analysis showed $\mathrm{OR}=2.000$ which means that mothers who got multiple pregnancy were 2.000 times at risk of suffering from premature rupture of membrane and there was a significant relation between malposition $\mathrm{p}$ value $=$ $0.000(<0.05)$ and premature rupture of membrane. Results also showed OR $=2.960$ which means that mothers who got pregnant with malposition were 2.960 times at risk of suffering from premature rupture of membrane. Results of bivariate analysis on education level showed $p$ value $=0.000$ which means that there was a significant relation between maternal education and premature rupture of membrane. Analysis also showed OR score = 3.632 which means that mothers attaining low level of education were 3.632 times more likely to suffer from premature rupture of membrane than mothers attaining high level of education.

All influential variables were then tested deeper to determine influence of or interaction between variables to premature rupture of membrane incidence by using multivariate logistic regression test. The test found three significant variables, namely age, parity and education. Multivariate analysis of this final model resulted $=0.198$, which means that three independent variables (age, parity and education) simultaneously showed $19.8 \%$ and premature rupture of membrane approximately $80 \%$. The most dominant variable was education with $\mathrm{OR}=$ 3.606 .

\section{Discussion}

There were more mothers suffering from premature rupture of membrane $(62.3 \%)$ in the group of risky age than in the group of not risky age $(37.7 \%)$. This result of study is in line with study conducted by Swarini, ${ }^{9}$ finding a significant relation between age of mothers and premature rupture of membrane incidence.

Age of mothers $<20$ years belongs to the too young age with less mature condition of uterus for giving birth, so risky of suffering from premature rupture of membrane. Meanwhile, age $>35$ years belongs to the too old age for giving birth, especially among old mothers and at high risk of suffering from premature rupture of membrane. ${ }^{10}$ Age $>35$ years also makes condition and function of uterus decreasing. One of causes is uterus tissue which is no longer fertile, meanwhile uterus wall is the place where placenta attached to. This condition raises a tendency of placenta previa occurrence or placenta does 
not attach to the place where it should be. Moreover, tissue of pelvic cavity and the muscles are weakening as in line with the age getting older. This makes the pelvic cavity no longer easy to face and solve heavy complications such as bleeding. In certain condition, its hormonal condition is not as optimum as the age before. That is why the risk of miscarriage, amniotic fluid leak, fetal death and other complications also increasing. Although the cause of premature rupture of membrane was not yet known certainly, but the possible predisposing factors were women's age younger than 20 years and older than 35 years, previous preterm birth and premature rupture of membrane records. ${ }^{7}$ The similar result was also found in study conducted by Purwanti et al., 11 that found relation between age of mothers and premature rupture of membrane incidence, birth-giving mothers aged $>35$ years end to have declining health and uterine condition, also the weak pelvic cavity and its muscles in line with the age getting older.

Different perspective was stated by study of Dars et $a l .{ }^{4}$ which showed that premature rupture of membrane incidence mostly occurred among patients aged $20-30$ years, but no significant relation was found between age and premature rupture of membrane incidence because premature rupture of membrane incidence in this study was influenced more by infection factor, the low socioeconomy and quality of antenatal care (ANC).

Results of statistical test analyzing relation between parity and premature rupture of membrane incidence found $\mathrm{p}$ value $=0.003, \mathrm{OR} 1.992, \mathrm{CI}=12.260-3.149$ which means that there was a significant relation between parity and premature rupture of membrane incidence. Based on results of multivariate logistic regression, variable parity had significant relation with premature rupture of membrane incidence. This is line with theory stating that women who experience pregnancy more than twice need to be more careful of because getting pregnant too often results the weak uterine condition as it is often in tense due to pregnancy. ${ }^{12}$

Multiparity is one of predisposing factors of premature rupture of membrane incidence because among multiparous women, incompetent cervix is often found, so there is no resistance on amniotic membrane. Parity (multi/grande multiparity) is the general cause of premature rupture of membrane incidence. ${ }^{13}$ Parity is one of factors causing premature rupture of membrane because the increase of parity which enables cervix damage during delivery before. The too many number of child is medical factor that becomes a background of maternal and perinatal mortality. The more number of born child is, it may decrease reproductive health with risks including abortus, preeclampsia, premature rupture of membrane and low birthweight. Multigravida mothers have risk of suffering from premature rupture of membrane incidence, so if there are multigravida mothers in pregnancy check, health officers are expected to make plans, therefore premature rupture of membrane would not occur or be handled without any complications. ${ }^{14}$

There was a significant relation between multiple pregnancy and premature rupture of membrane incidence as considered by $\mathrm{p}$ value $=0.000, \mathrm{OR}=2.676, \mathrm{CI}$ $=1.683-4.254$, which concluded that mothers with multiple pregnancy were 2.676 times more likely to get premature rupture of membrane incidence than mothers without multiple pregnancy. Results of this study are in accordance with a theory stating that cause of premature rupture of membrane could be due to excessive tension of uterus, such as multiple pregnancy, hydramnion, fetal malposition like breech. Then it could be due to infections that might raise biomechanical process on amniotic membrane, so premature rupture of membrane easy to occur. ${ }^{7}$ Multiple preganancy may raise excessive tension of uterus and at the end, it may raise contraction. If contraction is excessive while labor signs such as cervix opening is not yet maximum, thus premature rupture of membrane incidence may arise. ${ }^{15}$ The similar result of study was showed by Susilawati that there was relation between number of fetus and premature rupture of membrane incidence, the more number of fetus like in multiple pregnancy, it would make stomach in tense excessively, so premature rupture of membrane easy to occur. ${ }^{16}$

Chi square test on malposition or breech showed a significant relation between malposition and premature rupture of membrane incidence with $p$ value $=0.000(\mathrm{OR}$ $=2.960$ ). Result of this study was in line with theory that there was relation between malposition and premature rupture of membrane incidence. In malposition, the lowest position of fetus does not cover the birth canal, so there is no resistance on amniotic membrane that causes the easy leak of amniotic membrane. ${ }^{13}$ According to causes of premature rupture of membrane, malpositions namely breech and latitude position are possible because the lowest position of fetus does not cover the birth canal in maximum, so no resistance is found on amniotic membrane. ${ }^{11}$ Based on study conducted by Leihitu and Ruhyana, ${ }^{17}$ there was a relation between fetal malposition and premature rupture of membrane incidence.

In education, there was $\mathrm{OR}=2.379$ which means that mothers with high level of education (> junior high school) were 2.379 times more likely to get premature rupture of membrane than mothers with low level of education ( $<$ junior high school) and it was proven by chi square test analysis that maternal education and premature rupture of membrane incidence with $p=0.000$ showed a significant relation between maternal education and premature rupture of membrane incidence.

Based on multivariate logistic regression, there were 
three significant variables namely age, parity and education. This final of model multivariate analysis resulted = 0.198 , which means that three independent variables (age, parity and education) simultaneously showed $19.8 \%$ and premature rupture of membrane approximately $80 \%$. The most dominant variable was education with $\mathrm{OR}=3.606$.

Maternal education was one of causes of maternal mortality. High educated women tend to be more aware of health of themselves and their families as well as aware of nutritional and medical checkup at the time of pregnancy. Moreover, the high educated women would be more able to early detect any dangers during pregnancy.

Another study showed that formal education of women affected the use of maternal health services. In Thailand, maternal education is significantly influential to the use of health services. Mothers with higher education when suffering from premature rupture of membrane immediately came to the health services because they know it could affect on their health and baby. ${ }^{3}$

Level of education relates to knowledge that someone possesses, the higher education level of someone, the higher level of knowledge possessed, so easily health workers can tell about the importance of pregnancy checkup to anticipate high risk and complications during pregnancy. 18

\section{Conclusion}

Risk factors of premature rupture of membrane are age, parity and education, but the most dominant factor to premature rupture of membrane incidence is maternal education.

\section{Recommendation}

PROM has a great effect on maternal health. This study recommends pregnant women to increase education and knowledge to perform early detection of danger signs and complications during pregnancy, such as early PROM detection.

\section{References}

1. Aeni N. Faktor resiko kematian ibu. Kesmas: Jurnal Kesehatan Masyarakat Nasional [Internet]. 2013 [cited 11 Januari 2017]; 7(10): 453-9. Available from: http://journal.fkm.ui.ac.id/kesmas/article/ view/4

2. Badan Pusat Statistik. Survei demografi dan kesehatan Indonesia 2012. Jakarta: Badan Pusat Statistik. 2012.

3. Mahwati Y. Pemanfaatan pelayanan kesehatan ibu di Jawa Barat. Kesmas: Jurnal Kesehatan Masyarakat Nasional [Internet]. 2013 [cited 12 Januari 2017]; 7(6): 257-64. Available from: http://journal.fkm. ui.ac.id/kesmas/article/view/35
4. Dars S, Malik S, Samreen I, Kazi RA. Maternal morbidity and perinatal outcome in preterm premature rupture of membranes before 37 weeks gestation. Pakistan Journal of Medical Sciences. 2014 [cited 2016 April 11];30(3):626-9. Available from: http://www.ncbi.nlm.nih.gov/pmc/ articles/PMC4048519

5. Zhou Q, Zhang W, Xu H, Li X. Risk factors for preterm premature rupture of membrane in Chinese women from urban cities. International Journal of Gynekology and Obstetrics. 2015 [cited 2016 March 30]. 2014; 127(3): 254-9. Available from: https://www.ncbi.nlmnih.gov/pubmed/25200254

6. Hasaneroglu, Bakacak M, Suhhabostanci M, Eminesedaguvendagguven, Attar R, Ozgekizilkale, et al. Relationship between premature rupture of membranes and collagen amount in chorioamniotic membranes in term pregnancy. Global Journal of Medical Research. 2014 [cited 2016 April 25]; 10(2). Available from: https://globaljournals.org/GJMR_ Volume14/4

7. Prawirohardjo S. Ilmu kebidanan. Jakarta: Bina Pustaka. 2010.

8. Government of Western Australia Departement of Health. Complications of pregnancy preterm prelabour rupture of membranes (PPROM). [cited 2016 April 25]. Available from: http://www.kemh. health.wa.gov.au/development/manuals/O\&G_guidelines/sectionb/2/b 2.6.1.pdf

9. Swarini. Faktor - faktor yang berhubungan dengan kejadian ketuban pecah dini di RSUD Bayu Asih Kabupaten Purwakarta. [cited 2016 April 11]. Available from: http://onlinelibrary.wile.com

10. Nugroho T. Buku ajar obstetri. Yogyakarta: Nuha Medika. 2010.

11. Purwanti E, Afriyani LD, Rosalina. Faktor-faktor yang berhubungan dengan kejadian ketuban pecah dini Di RSUD Ungaran Kabupaten Semarang tahun 2014. [cited 2016 April 25]. Available from: http://perpusnwu.web.id/karyailmiah/documents/4239.pdf

12. Kementerian Kesehatan Republik Indonesia. Pedoman seri kesehatan maternal. Jakarta: Departemen Kementerian Kesehatan Republik Indonesia. 2011.

13. Manuaba IBG. Kapita selekta penatalaksanaan obstetri ginekologi dan KB. Jakarta: EGC: 2010.

14. Morgan G, Carole H. Obstetri dan ginekologi. Jakarta: EGC. 2009.

15. Siregar FA. Faktor -faktor yang mempengaruhi terjadinya ketuban pecah dini di rumah sakit umum daerah Padangsidimpuan. [cited 2016 April 17]. Available from: http//respirotory.usu.ac.id/handle/123456789/24515

16. Susilawati. Analisis faktor-faktor yang mempengaruhi kejadian ketuban pecah dini (KPD) Di RSUD Cilacap [Skripsi]. Surakarta: Universitas Sebelas Maret; 2011 [cited 2016 April 25]. Available from: http://digilib.uns.ac.id

17. Leihitu FY, Ruhyana. Faktor-faktor yang berhubungan dengan ketuban pecah dini pada ibu bersalin di RSUD Sleman [Skripsi]. Yogyakarta: Sekolah Tinggi Ilmu Kesehatan 'Aisyiyah: 2015 [cited 2016 April 25]. Available from: http://opac.say.ac.id/15/ 1/NASKAH/PUBLIKASI_

18. Aisyah A. Perbedaan kejadian ketuban pecah dini antara primipara dan multipara. Jurnal Midpro [internet]. 2012: (1): 1-7. Available from: http://journal.unisla.ac.id/pdf/19412012/1 